\title{
Defective amplification of the late phase insulin response to glucose by GIP in obese Type II diabetic patients
}

\author{
T. Vilsbøll' ${ }^{1,2}$, T. Krarup 1 , S. Madsbad ${ }^{3}$, J. J. Holst ${ }^{2}$ \\ ${ }^{1}$ Departments of Internal Medicine F, Gentofte Hospital, Copenhagen, Denmark \\ ${ }^{2}$ Department of Medical Physiology, Panum Institute, Copenhagen, Denmark \\ ${ }^{3}$ Department of Endocrinology, Hvidovre Hospital, Copenhagen, Denmark
}

\section{Abstract}

Aims/hypothesis. Glucagon-like-peptide-1 (GLP-1) is strongly insulinotropic in patients with Type II (noninsulin-dependent) diabetes mellitus, whereas glucose-dependent insulinotropic polypeptide (GIP) is less effective. Our investigation evaluated "early" (protocol 1) - and "late phase" (protocol 2) insulin and C-peptide responses to GLP-1 and GIP stimulation in patients with Type II diabetes.

Methods. Protocol 1: eight Type II diabetic patients and eight matched healthy subjects received i.v. bolus injections of GLP-1(2.5 nmol) or GIP(7.5 nmol) concomitant with an increase of plasma glucose to $15 \mathrm{mmol} / \mathrm{l}$. Protocol 2: eight Type II diabetic patients underwent a hyperglycaemic clamp $(15 \mathrm{mmol} / \mathrm{l})$ with infusion (per $\mathrm{kg}$ body weight $/ \mathrm{min}$ ) of either: 1 pmol GLP-1 (7-36) amide $(n=8), 4$ pmol GIP $(n=8)$, 16 pmol GIP $(n=4)$ or no incretin hormone $(n=5)$. For comparison, six matched healthy subjects were examined.

Results. Protocol 1: Type II diabetic patients were characterised by a decreased "early phase" response to both stimuli, but their relative response to GIP versus GLP-1 stimulation was exactly the same as in

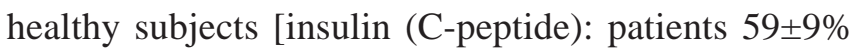
$(74 \pm 6 \%)$ and healthy subjects $62 \pm 5 \%(71 \pm 9 \%)]$. Protocol 2, "Early phase" (0-20 min) insulin response to glucose was delayed and reduced in the patients, but enhanced slightly and similarly by GIP and GLP-1. GLP-1 augmented the "late phase" (20-120 min) insulin secretion to levels similar to those observed in healthy subjects. In contrast, the "late phase" responses to both doses of GIP were not different from those obtained with glucose alone. Accordingly, glucose infusion rates required to maintain the hyperglycaemic clamp in the "late phase" period (20-120 min) were similar with glucose alone and glucose plus GIP, whereas a doubling of the infusion rate was required during GLP-1 stimulation.

Conclusion/interpretation. Lack of GIP amplification of the late phase insulin response to glucose, which contrasts markedly to the normalising effect of GLP-1, could be a key defect in insulin secretion in Type II diabetic patients. [Diabetologia (2002) 45:1111-1119]

Keywords Glucagon-like peptide-1, glucose-dependent insulinotropic polypeptide, incretin hormones, GIP receptors, insulin secretion.
Received: 8 October 2001 / Revised: 25 February 2002 Published online: 4 July 2002

(C) Springer-Verlag 2002

Corresponding author: T. Vilsbøll, MD, Department of Internal Medicine F, Gentofte Hospital, University of Copenhagen, Niels Andersens Vej 65, DK-2900 Hellerup, Denmark. E-mail: tivi@gentoftehosp.kbhamt.dk

Abbreviations: GLP-1, Glucagon-like peptide-1; GIP, glucosedependent insulinotropic polypeptide; FPG, fasting plasma glucose; AUC, area under curve; DPP-IV, dipeptidyl peptidase IV.
Glucagon-like-peptide-1 (GLP-1) and glucose-dependent insulinotropic polypeptide (GIP) are insulinotropic incretin hormones that are released from the intestine in response to ingestion of a mixed meal. Together, they are responsible for the so-called incretin effect, i.e. the enhanced insulin secretion after oral versus intravenous administration of glucose [1]. Patients with Type II (non-insulin-dependent) diabetes are characterised by an impaired incretin effect [2,3]. Recently, we presented data showing near normal GIP secretion, but re- 
duced postprandial concentrations of total and intact, biologically active GLP-1 in Type II diabetic patients, which might explain part of the impaired incretin effect in Type II diabetes [4]. Previous studies have indicated that whereas GLP-1 is strongly insulinotropic in patients with Type II diabetes mellitus, the effect of GIP is much weaker or absent $[5,6]$; although, in another study, GIP appeared to retain some activity [7]. The effect of GIP in Type II diabetic patients is an important issue, because a defect in GIP action could contribute to the impaired incretin function. It is difficult to differentiate between a selective impairment of beta-cell responsiveness to GIP and the general beta-cell dysfunction in Type II diabetes. In our study, we investigated more closely the potentiating insulinotropic effects of GIP, using the preserved response to GLP-1 as a measure of the functional beta-cell mass [8]. In this way a defective responsiveness to GIP could be quantitated. The study was divided into two parts. In protocol 1, we compared the "early phase" insulin and C-peptide responses after stimulation with a single bolus injection of either GIP or GLP-1 combined with an acute increase of PG to $15 \mathrm{mmol} / \mathrm{l}$ in Type II diabetic patients and healthy subjects. In protocol 2, a continuous infusion of the incretin hormones under the conditions of a hyperglycaemic clamp at $15 \mathrm{mmol} / \mathrm{l}$, was used to provide a prolonged stimulation of the beta cell to estimate both "early" and "late phase" insulin and C-peptide responses.

\section{Subjects and methods}

Subjects. For the first protocol we studied eight Type II diabetic patients (six men, two women); mean age: 59 years (4869 years); BMI: $31.6 \mathrm{~kg} / \mathrm{m}^{2}\left(26.0-37.7 \mathrm{~kg} / \mathrm{m}^{2}\right)$; $\mathrm{HbA}_{1 \mathrm{C}}: 8.9 \%$ (7.0-11.1\%); fasting plasma glucose (FPG): $10.0 \mathrm{mmol} / \mathrm{l}$ (8.2-13.2 $\mathrm{mmol} / \mathrm{l})$; mean duration of diabetes: 42 months (7-97 months), and eight matched healthy subjects: mean age: 58 years (51-70 years); BMI: $31.9 \mathrm{~kg} / \mathrm{m}^{2}\left(26.4-37.9 \mathrm{~kg} / \mathrm{m}^{2}\right)$; FPG: $5.6 \mathrm{mmol} / \mathrm{l}(5.2-6.4 \mathrm{mmol} / \mathrm{l}) ; \mathrm{HbA}_{1 \mathrm{C}}: 5.6 \%(5.2-6.0 \%)$. Four patients were treated with diet alone while four were treated with diet and oral antidiabetics (biguanides and/or sulfonylureas). Five patients had a history of hypertension and were treated with thiazides, ACE-inhibitors and calcium antagonists.

For the second protocol we studied eight Type II diabetic patients (seven men, one woman); mean age: 55 years $(49$ 59 years); BMI: $29.5 \mathrm{~kg} / \mathrm{m}^{2}\left(27.6-34.4 \mathrm{~kg} / \mathrm{m}^{2}\right) ; \mathrm{HbA}_{1 \mathrm{C}}: 7.4 \%$ (5.3-9.8\%); FPG: $10.1 \mathrm{mmol} / \mathrm{l}(7.6-13.7 \mathrm{mmol} / \mathrm{l})$; mean duration of diabetes: 71 months (13-228 months), and six matched healthy subjects (five men, one woman); mean age: 54 years (48-63 years); BMI: $29.6 \mathrm{~kg} / \mathrm{m}^{2}\left(27.1-35.6 \mathrm{~kg} / \mathrm{m}^{2}\right)$; FPG: $5.6 \mathrm{mmol} / \mathrm{l}(5.3-5.9 \mathrm{mmol} / \mathrm{l}) \mathrm{HbA}_{1 \mathrm{C}}: 5,6 \%$ (5,1-6.3\%). Three patients were treated with diet alone while five were treated with diet and oral antidiabetics (biguanides and/or sulfonylureas). One patient had a history of hypertension and was treated with an ACE-inhibitor.

The subjects studied in both protocols were chosen to represent typical outpatient obese Type II diabetic patients and they were all diagnosed according to the criteria of the World Health Organisation (WHO) $[9,10]$. None of the patients had impaired renal function (serum creatinine concentrations $<130 \mu \mathrm{mol} / \mathrm{l}$ and no albuminuria), proliferative retinopathy or impaired liver function. None of the healthy subjects had a family history of diabetes and all had a normal OGTT. All agreed to participate and gave their oral and written consent. The study was approved by the Copenhagen County Ethics Committee, dated 13 March 1998 (journal number in the Committee: KA 97176m) and the study was conducted according to the principles of the Helsinki Declaration.

Methods. All oral antidiabetics were discontinued before the study (sulfonylureas 3 days before the study, biguanides 7 days before the study). After an overnight fast (from 10:00 pm), the subjects were studied recumbent with two cannulas inserted into the cubital veins, one for injection of either GIP, GLP-1 and/or glucose and one for blood sampling.

In the first protocol in randomised order a combined GLP-1+glucose (day 1) or a combined GIP plus glucose (day 2) stimulation was carried out on two different days. At time zero $(0 \mathrm{~min}), 50 \%$ glucose $(\mathrm{w} / \mathrm{v})$ was infused during $1 \mathrm{~min}$ to increase the plasma glucose to $15 \mathrm{mmol} / \mathrm{l}$ (the amount of glucose given was calculated as follows: (15 mmol/l-fasting plasma glucose) $\times 35 \mathrm{mg}$ glucose $\times$ weight in kilogram). After $3 \mathrm{~min}, 2.5 \mathrm{nmol}$ of GLP-1 or $7.5 \mathrm{nmol}$ of GIP was injected as a bolus injection during 2 min. Venous blood was sampled 15, 10 and 0 min before and 5, 6, 7, 9, 11, 13, 18, 23, 28, 33 and 48 min after the i.v. bolus of glucose.

The second protocol of the study included 4 experimental days. The experiments were carried out in randomised order and consisted of a hyperglycaemic clamp (15 mmol/l) with or without continuous infusion of incretin hormones. At time zero $(0 \mathrm{~min}), 50 \%$ glucose $(\mathrm{w} / \mathrm{v})$ was infused during $1 \mathrm{~min}$ to increase the plasma glucose to $15 \mathrm{mmol} / \mathrm{l}$ (calculated as in protocol 1). Plasma glucose was kept at $15 \mathrm{mmol} / \mathrm{l}$ by continuous infusion of glucose, which was adjusted every 5 min according to bedside measurements of plasma glucose. After $3 \mathrm{~min}$, a continuous infusion of incretin hormones (pmol/per.kg body weight/min) was initiated: 1 pmol GLP-1 (7-36) amide (day 1), 4 pmol GIP (day 2), 16 pmol GIP (day 3, $n=4$ ) or no incretin hormone (day $4, n=5$ ). Blood was sampled 15, 10 and 0 min before and $5,10,15,20,25,30,45,60,75,90,105,120$, $150,180,210$ and $240 \mathrm{~min}$ after the increase of plasma glucose. We studied three patients for only $120 \mathrm{~min}$. The healthy subjects participated in day 2 and day 4 experiments only and for only 120 min. Hyperglycaemic clamp with GLP-1 infusion was carried out in only one healthy subject, in whom insulin and C-peptide (in brackets) concentrations after $120 \mathrm{~min}$ amounted to: 13770 (22380) pmol/l: his total "early phase" insulin $\mathrm{AUC}_{(0-20 \mathrm{~min})}$ was $11.3520 \mathrm{~min} \times \mathrm{nmol} / \mathrm{l}$ and his total "late phase" insulin response $\left(\mathrm{AUC}_{(20-120 \mathrm{~min})}\right.$ ) was 593.12 $100 \mathrm{~min} \times \mathrm{nmol} / \mathrm{l}$. As a result of the excessive insulin response in this healthy subject, plasma glucose concentrations decreased below $3 \mathrm{mmol} / \mathrm{l}$ for approximately $1 \mathrm{~h}$ after termination of the experiment in spite of food ingestion. Due to the dramatic effect of GLP-1 during a hyperglycaemic clamp at $15 \mathrm{mmol} / \mathrm{l}$, we considered it unethical to continue the GLP-1 experiments in the remaining healthy subjects.

Blood was sampled into fluoride tubes for plasma glucose analysis and into heparin-tubes and EDTA tubes $(6 \mathrm{mmol} / \mathrm{l})$ with aprotinin $(500 \mathrm{KIU} / \mathrm{ml}$ blood; Trasylol, Bayer, Leverkusen, Germany) for hormone analyses. Tubes were immediately cooled on ice and centrifuged at $4^{\circ} \mathrm{C}$ within $20 \mathrm{~min}$. Plasma was stored at minus $20^{\circ} \mathrm{C}$ until analysis (plasma for insulin and C-peptide analysis were stored at minus $80^{\circ} \mathrm{C}$ ).

Peptides. Synthetic GLP-1(7-36) amide was purchased from Peninsula Europe (Merseyside, UK) and synthetic GIP from 
PolyPeptide Laboratories (Wolfenbüttel, Germany). The peptides were dissolved in sterilised water containing $2 \%$ human serum albumin (Human Albumin, Statens Serum Institute, Denmark, guaranteed to be free of hepatitis-B surface antigen, hepatitis- $\mathrm{C}$ virus antibodies and human immunodeficiency virus antibodies) and subjected to sterile filtration. Appropriate amounts of peptide for each experimental subject were dispensed into glass ampoules and stored frozen under sterile conditions until the day of the experiment. The peptides were more than $97 \%$ pure and identical to the natural human peptides by HPLC, mass, and sequence analysis.

Analysis. Plasma glucose concentrations were measured during the experiments using a glucose oxidase method and a Glucose Analyser (Yellow Springs Instrument Model: YSI 2300 STAT plus analyser, Ohio, USA). Plasma insulin concentrations were measured using commercial ELISA kits (Dako, Copenhagen, Denmark). The detection limit is approximately $3 \mathrm{pmol} / \mathrm{l}$, and the intra-assay and inter-assay coefficients of variation are 4 to $10 \%$ at 39 to $1.240 \mathrm{pmol} / \mathrm{l}$. In protocol $1, \mathrm{C}$-peptide concentrations were measured by radioimmunoassay (RIA) [11] using the polyclonal antibody M1230 [12]. The detection limit is approximately $60 \mathrm{pmol} / \mathrm{l}$, the intra-assay coefficient of variation is $5 \%$, and the inter-assay coefficient of variation is $7.3 \%$. In protocol 2, C-peptide concentrations were measured by ELISA kits (Dako, Copenhagen, Denmark). Intra-assay and interassay coefficients of variation for C-peptide are 3 to $6 \%$ at 380 to $2700 \mathrm{pmol} / \mathrm{l}$. The cross-reactivity with intact and split proinsulin in the C-peptide assay is $63-87 \%$.Total GIP was measured using the C-terminally directed antiserum R65 [13, 14], which reacts fully with intact GIP and the N-terminally truncated metabolite, GIP (3-42). The assay has a detection limit of less than $2 \mathrm{pmol} / \mathrm{l}$ and an intra-assay variation of approximately $6 \%$. Intact, biologically active GIP was measured using a newly developed assay [15]. The assay is specific for the intact N-terminus of GIP, and cross-reacts less than $0.1 \%$ with GIP (3-42), or with the structurally related peptides GLP-1 (7-36)amide, GLP-1 (9-36)amide, GLP-2 (1-33), GLP-2 (3-33) or glucagon at concentrations of up to $100 \mathrm{nmol} / \mathrm{l}$. Intra-assay variation was less than $6 \%$ and inter-assay variation was approximately 8 and $12 \%$ for 20 and $80 \mathrm{pmol} / \mathrm{l}$ standards, respectively. Plasma samples were assayed for GLP-1 immunoreactivity using RIAs which are specific for each terminus of the GLP-1 molecule: the C-terminal assay measuring the sum of the intact peptide plus the primary metabolite and the $\mathrm{N}$-terminal assay measuring the concentration of intact surviving GLP-1. The C-terminal immunoreactivity of GLP-1 was measured [16], using standards of synthetic GLP-1 (7-36) amide (= proglucagon 78-107amide) and antiserum no. 89390. The assay cross-reacts less than $0.01 \%$ with C-terminally truncated fragments, and $83 \%$ with GLP-1 (9-36) amide and has a detection limit below $1 \mathrm{pmol} / \mathrm{l}$. N-terminal immunoreactivity was measured using antiserum 93242 [17], which cross-reacts approximately $10 \%$ with GLP-1 (1-36) amide, and less than $0.1 \%$ with GLP-1 (8-36) amide and GLP-1 (9-36) amide. The assay has a detection limit of $2 \mathrm{pmol} / \mathrm{l}$. For both assays intraassay and inter-assay coefficients of variation were below $6 \%$ and $15 \%$, respectively, at $40 \mathrm{pmol} / \mathrm{l}$. The glucagon assay is directed against the $\mathrm{C}$-terminus of the glucagon molecule (antibody code no. 4305) and therefore measures glucagon of mainly pancreatic origin. The sensitivity is approximately $1 \mathrm{pmol} / \mathrm{l}$, and the intra-assay coefficient of variation is below $6 \%$ in the range between 10 and $25 \mathrm{pmol} / 1$ [18].

Statistical analysis and calculations. All results are shown as the mean \pm SEM. Statistical analysis was carried out as two factor analysis of variance for repeated measurements with
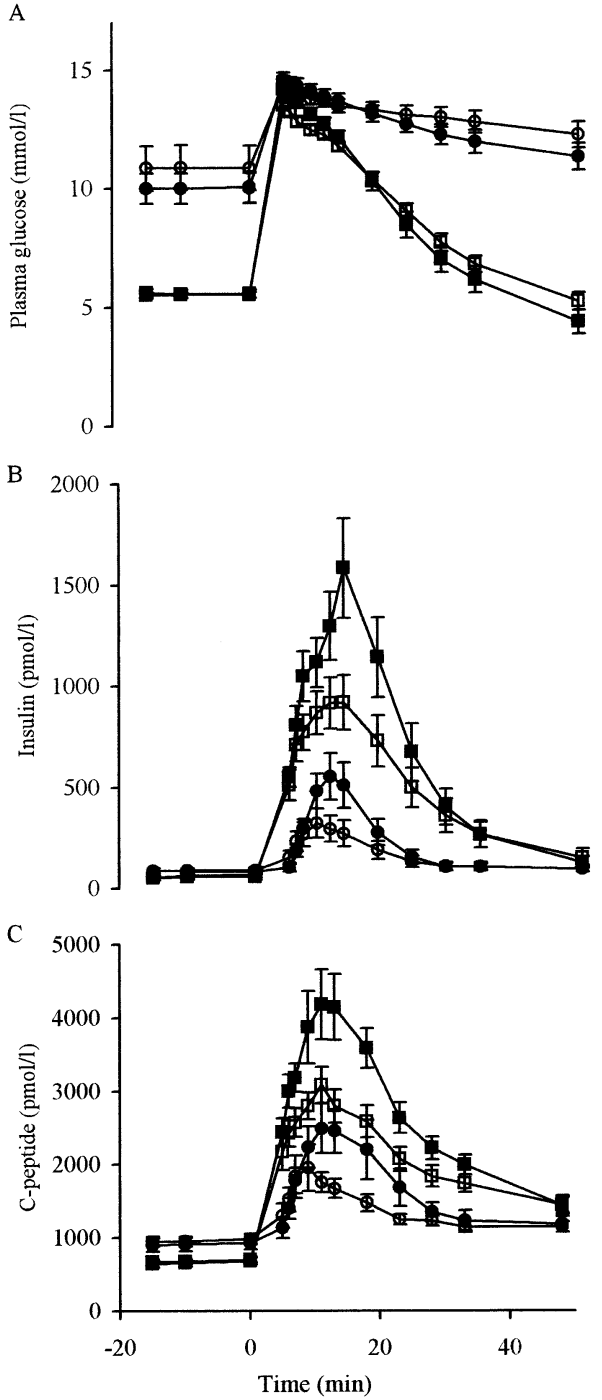

Fig. 1A-C. Plasma glucose (A), insulin (B) and C-peptide concentrations $(\mathbf{C})$ during part 1 of the study. Type II diabetic patients: day $1_{\text {(GLP-1) }}$ (solid circles) and day $2_{(\mathrm{GIP})}$ (open circles). Healthy subjects: day $1_{(\mathrm{GLP}-1)}$ (solid squares) and day $2_{(\mathrm{GIP})}$ (open squares). Data are means $\pm \mathrm{SEM}$

post hoc analysis contrasting patient results versus healthy subjects using Statistica software (Statsoft, Tulsa, Okla., USA). AUCs were calculated using the trapezoidal rule and compared using the Wilcoxon Test for pair differences.

\section{Results}

In the first protocol FPG were between 7.8 and $14.8 \mathrm{mmol} / \mathrm{l}$ in the Type II diabetic patients and between 4.9 and $6.1 \mathrm{mmol} / \mathrm{l}$ in the healthy subjects. Peak plasma glucose concentrations were similar after glucose administration in both patients and healthy subjects and did not differ on the two different experimental days (Fig. 1A).

Time courses of insulin and C-peptide responses are shown (Fig. 1B,C). Peak concentrations of insulin and C-peptide occurred between 9 and 13 min after 
Table 1. Insulin responses and C-peptide responses during part one of the study

\begin{tabular}{|c|c|c|c|c|}
\hline & \multicolumn{2}{|c|}{ GLP-1 bolus (2.5 nmol) } & \multicolumn{2}{|c|}{ GIP bolus $(7.5 \mathrm{nmol})$} \\
\hline & $\begin{array}{l}\text { Type II diabetic } \\
\text { patients }\end{array}$ & Healthy subjects & $\begin{array}{l}\text { Type II diabetic } \\
\text { patients }\end{array}$ & Healthy subjects \\
\hline Peak insulin means \pm SEM & $553 \pm 116$ & $1584 \pm 246$ & $323 \pm 72$ & $919 \pm 135$ \\
\hline Total AUC, insulin $(48 \min \times n m o l / 1)$ & $9.49 \pm 1.81$ & $29.24 \pm 4.58$ & $7.45 \pm 1.39$ & $22.09 \pm 3.69$ \\
\hline Peak C-peptide means \pm SEM & $2491 \pm 335$ & $4182 \pm 478$ & $1936 \pm 320$ & $3083 \pm 247$ \\
\hline Total AUC, C-peptide (48 min×nmol/1) & $75.18 \pm 8.41$ & $120.33 \pm 7.62$ & $62.62 \pm 4.90$ & $96.74 \pm 6.38$ \\
\hline
\end{tabular}
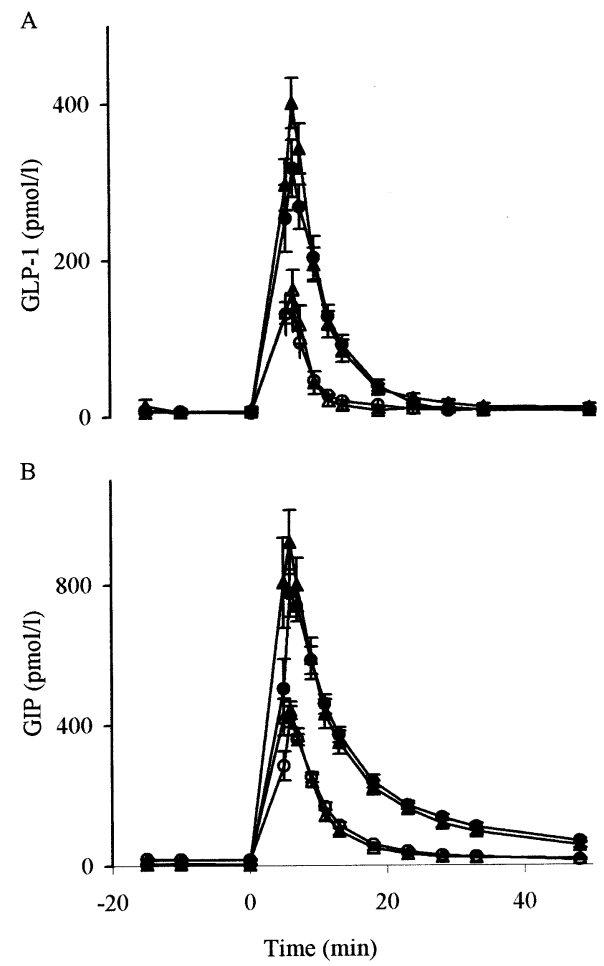

Fig. 2A, B. A Plasma GLP-1 during GLP-1 stimulation in part 1 of the study. Type II diabetic patients: Total GLP-1 (solid triangles) and intact GLP-1 (open triangles). Healthy subjects: Total GLP-1 (solid circles) and intact GLP-1 (open circles). B Plasma GIP during GIP stimulation in part 1 of the study. Type II diabetic patients: Total GIP (solid triangles) and intact GIP (open triangles). Healthy subjects: Total GIP (solid circles) and intact GIP (open circles). Data are means \pm SEM

injection of incretin hormones (AUCs and peak concentrations are shown in Table 1). Peak insulin and C-peptide concentrations were less in the Type II diabetic patients compared to the healthy subjects after GLP-1 and GIP injections, respectively (Table 1). Comparison of individual peak insulin and C-peptide concentrations showed smaller responses in both patients and healthy subjects after GIP stimulation compared to GLP-1 stimulation (insulin: patients $59 \pm 9 \%$ and healthy subjects $62 \pm 5 \%$; C-peptide: $74 \pm 6 \%$ and $71 \pm 9 \%$, respectively).

Basal plasma GLP-1 (day 1, Fig. 2A) and GIP (day 2, Fig. 2B) concentrations were between 1 and $30 \mathrm{pmol} / \mathrm{l}$ (both $\mathrm{C}$-terminal and $\mathrm{N}$-terminal). Peak

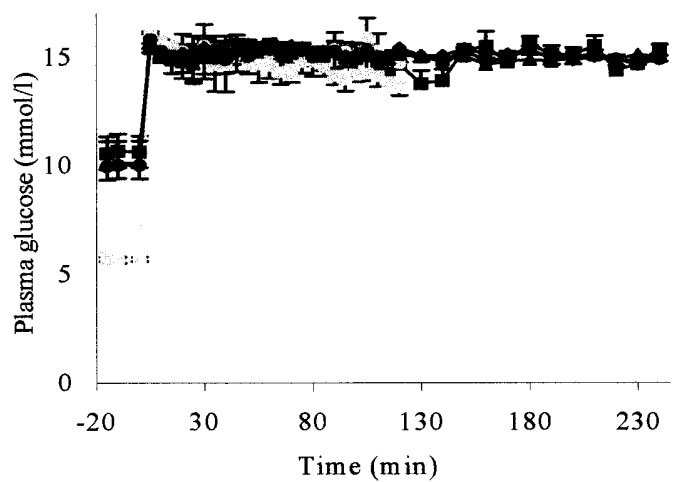

Fig. 3. Plasma glucose concentrations during part 2 of the study. Type II diabetic patients: day $1_{\mathrm{GLP}-1}$ (solid squares), day $2_{\text {Low GIP }}$ (open circles), day $3_{\text {High GIP }}$ (solid circles), day $4_{\text {Glucose }}\left(\right.$ solid diamonds). Healthy subjects: day $2_{\text {Low GIP }}$ (grey circles), day $4_{\text {Glucose }}($ grey squares). Data are means \pm SEM

plasma concentrations (means \pm SEM) in Type II diabetic patients and healthy subjects were similar with respect to total GIP [920 \pm 91 vs $775 \pm 68 \mathrm{pmol} / \mathrm{l}(\mathrm{NS})]$, intact GIP [442 \pm 25 vs $424 \pm 30 \mathrm{pmol} / \mathrm{l}(\mathrm{NS})]$ and intact GLP-1 $[162 \pm 25$ vs $140 \pm 32$ pmol/l(NS)]. Total peak GLP-1 concentrations were slightly higher in Type II diabetic patients $(401 \pm 32 \mathrm{pmol} / \mathrm{l})$ compared to healthy subjects $(317 \pm 36 \mathrm{pmol} / \mathrm{l})(p=0.049)$. Basal concentrations of both incretin hormones (total as well as intact) were reached again 15 to 25 min after i.v. injection.

In the second protocol mean FPG was between 10.0 and 10.6 (range $7.5-14.9$ ) $\mathrm{mmol} / \mathrm{l}$ on the four different experimental days (NS) in the Type II diabetic patients. In the healthy subjects, mean FPG was $5.6 \mathrm{mmol} / \mathrm{l}$ (range 4.7-6.2, day 2) and $5.7 \mathrm{mmol} / \mathrm{l}$ (range 5.1-6.1, day 4). Time courses of plasma glucose during the hyperglycaemic clamps were not significantly different on the experimental days (Fig. 3).

Time courses of insulin and C-peptide responses are shown in Fig. 4 and peak concentrations together with AUCs are shown in Table 2. Total as well as incremental "early phase" insulin and C-peptide $\mathrm{AUCs}_{(0-20 \mathrm{~min})}$ in Type II diabetic patients were considerably impaired and delayed compared to control subjects, but were not significantly different on the three different experimental days with GLP-1, low or high dose GIP stimulation although the response tended to be decreased after low GIP compared to 

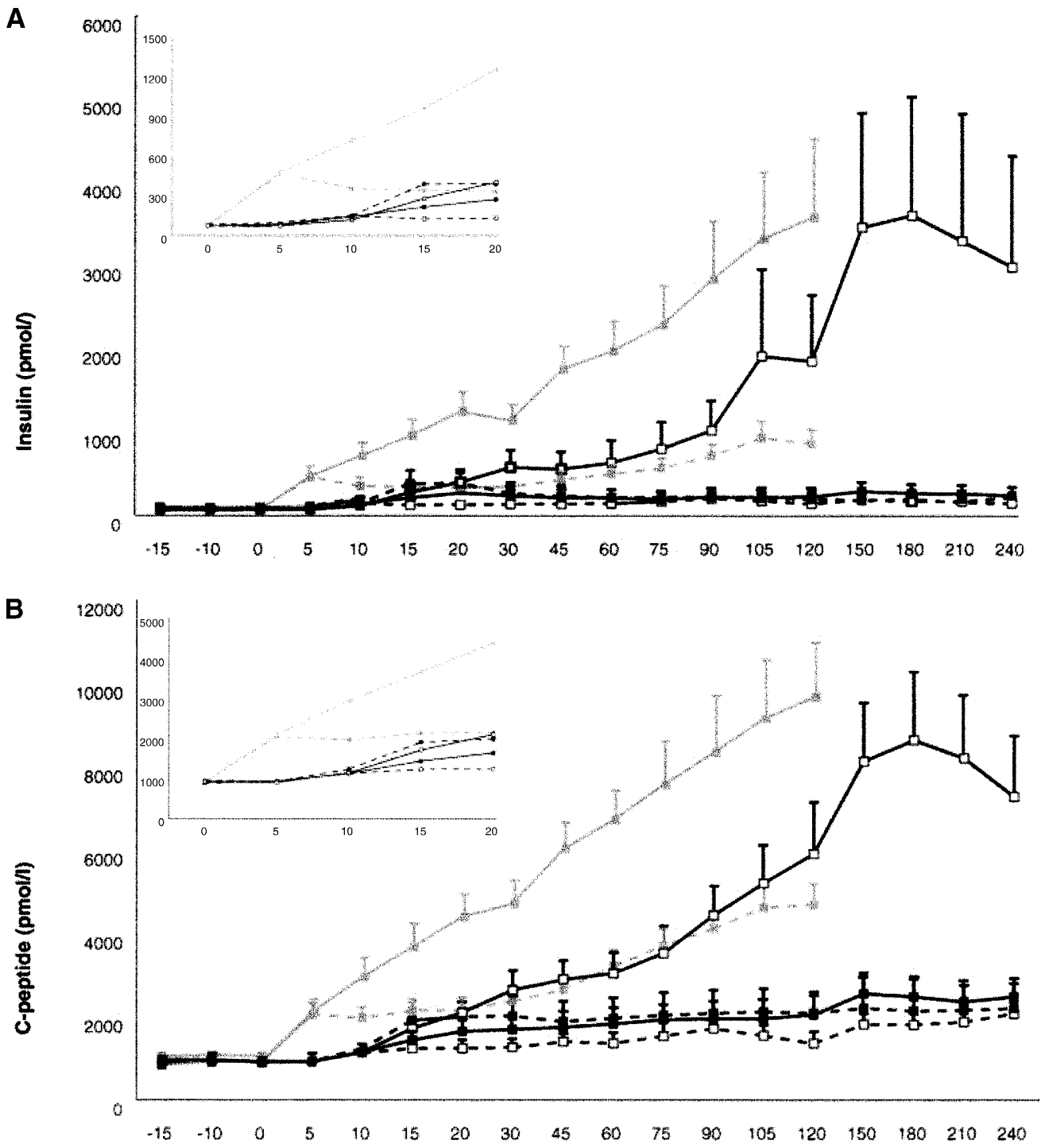

Fig. 4A, B. Part 2 of the study: Insulin (A) and C-peptide concentrations (B) for Type II diabetic patients (day $1_{\mathrm{GLP}-1}$ (open squares and solid line), day $2_{\text {Low GIP }}$ (solid squares and solid line), day $3_{\mathrm{High}} \mathrm{GIP}$ (solid squares and broken line), day $4_{\mathrm{Glucose}}$ (open squares and broken line). Healthy subjects (day $2_{\text {Low GIP }}$ (grey squares and solid grey line), day $4_{\mathrm{Glucose}}$ (grey squares and broken grey line). Inserted figure $(\mathbf{A}, \mathbf{B})$ show insulin responses during the first $20 \mathrm{~min}$. Data are means \pm SEM

high GIP and GLP-1 stimulation (Fig. 4). Comparison of "early phase" insulin and C-peptide incremental $\mathrm{AUCs}_{(0-20 \mathrm{~min})}$ showed greater responses after GLP-1, low and high GIP compared to glucose alone $(n=5$, two factor analysis of variance, insulin: $p=0.013$, C-peptide $=0.039)$. "Late phase" insulin and C-peptide responses $\left(\mathrm{AUC}_{(20-120 \mathrm{~min})}\right)$ were higher after GLP-1 stimulation compared to low dose GIP (4 pmol/per.kg body weight $/ \mathrm{min})$ in Type II diabetic patients $(p<0.01)$. As insulin secretion was still rising after $2 \mathrm{~h}$, a $4 \mathrm{~h}$ clamp was carried out in five of the Type II diabetic patients. "Late phase", total insulin and C-peptide
$\mathrm{AUCs}_{(20-240 \mathrm{~min})}$ in these patients were: $338.19 \pm 224.68$ (902.09 \pm 247.76$) 220 \mathrm{~min} \times \mathrm{nmol} / \mathrm{l}$ during GLP-1 infusion, $40.41 \pm 21.26(332.29 \pm 97.52) 220 \mathrm{~min} \times \mathrm{nmol} / \mathrm{l}$ during low GIP infusion, 45.00 \pm 16.64 (463.06 \pm 110.99) $220 \mathrm{~min} \times \mathrm{nmol} / \mathrm{l}$ during high GIP $(n=4)$ infusion and 23.64 $\pm 11.26(449.06 \pm 54.53) 220 \mathrm{~min} \times \mathrm{nmol} / \mathrm{l}$ during glucose only. In the healthy subjects, "early and late phase" insulin and C-peptide responses were: $14.02 \pm 2.82(56.94 \pm 7.78) 20 \mathrm{~min} \times \mathrm{nmol} / \mathrm{l}$ and $229.79 \pm$ $47.05(721.09 \pm 89.71) 100 \mathrm{~min} \times \mathrm{nmol} / \mathrm{l}$ after low dose GIP infusion. Corresponding results were: $6.80 \pm 1.39$

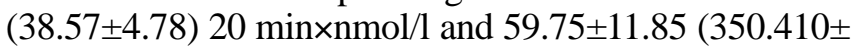
39.59) $100 \mathrm{~min} \times \mathrm{nmol} / \mathrm{l}$, respectively, after glucose only (Fig. 4, Table 2).

During GLP-1 stimulation, total and intact GLP-1 plasma concentrations increased rapidly during the first $20 \mathrm{~min}$ and peak concentrations for total and intact GLP-1 were reached between 105 and $120 \mathrm{~min}$ and amounted to $126 \pm 5 \mathrm{pmol} / \mathrm{l}$ and $13 \pm 3 \mathrm{pmol} / \mathrm{l}$, respectively (Fig. 5A). During low dose GIP (4 pmol $\left.\cdot \mathrm{kg}^{-1} \cdot \mathrm{min}^{-1}\right)$, total and intact (in brackets) GIP peak concentrations were reached between 105 and 
Table 2 Insulin responses and C-peptide responses during part two of the study

\begin{tabular}{|c|c|c|c|c|c|c|}
\hline & \multirow{2}{*}{$\begin{array}{l}\text { Day } 1 \text { GLP-1 } \\
(1 \mathrm{pmol} / \mathrm{kg} / \mathrm{min}) \\
\text { Patients }\end{array}$} & \multicolumn{2}{|c|}{ Day 2 GIP (4 pmol/kg/min) } & \multirow{2}{*}{$\begin{array}{l}\text { Day } 3 \mathrm{GIP} \\
\text { (16 pmol/kg/min) } \\
\text { Patients }\end{array}$} & \multicolumn{2}{|c|}{ Day 4 No incretin hormone } \\
\hline & & Patients & $\begin{array}{l}\text { Control } \\
\text { subjects }\end{array}$ & & Patients & $\begin{array}{l}\text { Control } \\
\text { subjects }\end{array}$ \\
\hline $\begin{array}{l}\text { Peak insulin } \\
\text { means } \pm \text { SEM, (min) }\end{array}$ & $1917 \pm 1041(105)$ & $272 \pm 91(20)$ & $3580 \pm 948$ (120) & $390 \pm 147(20)$ & $207 \pm 78(90)$ & $935 \pm 207$ (105) \\
\hline $\begin{array}{l}\text { Total } \mathrm{AUC}_{(20-120 \mathrm{~min})} \\
\text { insulin } \\
(100 \mathrm{~min} \times \mathrm{nmol} / \mathrm{l}) \\
\text { means } \pm \mathrm{SEM}\end{array}$ & $97.21 \pm 41.66$ & $22.19 \pm 7.61$ & $229.79 \pm 47.05$ & $23.46 \pm 9.25$ & $16.14 \pm 5.19$ & $59.75 \pm 11.85$ \\
\hline $\begin{array}{l}\text { Total AUC } \mathrm{AU}_{(20-120 \mathrm{~min})} \\
\text { C-peptide } \\
(100 \mathrm{~min} \times \mathrm{nmol} / \mathrm{l}) \\
\text { means } \pm \mathrm{SEM}\end{array}$ & $374.94 \pm 63.67$ & $186.64 \pm 35.60$ & $721.09 \pm 89.71$ & $202.91 \pm 50.65$ & $146.04 \pm 24.74$ & $350.41 \pm 39.59$ \\
\hline
\end{tabular}

$120 \mathrm{~min}$ and amounted to $422 \pm 31(219 \pm 11) \mathrm{pmol} / \mathrm{l}$ in the Type II diabetic patients and $452 \pm 24(250 \pm 5) \mathrm{pmol} / \mathrm{l}$ in the healthy subjects. Corresponding results were $2222 \pm 168(1246 \pm 237) \mathrm{pmol} / \mathrm{l}$ during high dose GIP (a concentration exceeding normal postprandial concentrations by a factor 10-20) (Fig. 5B).

Glucagon responses during protocol 2 are shown in Fig. 5C. During the hyperglycaemic clamp without concomitant infusion of incretin hormone, glucagon responses were considerably decreased in the healthy subjects $[10.0 \pm 0.7 \mathrm{pmol} / \mathrm{l}$ (fasting) vs $2.7 \pm 0.3 \mathrm{pmol} / 1$ after $120 \mathrm{~min}$ ], whereas only a small decrease was seen in the Type II diabetic patients $[8.4 \pm 1.4 \mathrm{pmol} / \mathrm{l}$ (fasting) vs $5.8 \pm 1.3 \mathrm{pmol} / 1$ after $120 \mathrm{~min}$ ]. No further decrease in glucagon response was seen in the healthy subjects with GIP stimulation. GLP-1 stimulation in Type II diabetic patients resulted in a marked decrease in glucagon secretion $[9.5 \pm 0.8 \mathrm{pmol} / \mathrm{l}$ (fasting) vs $2.9 \pm 0.6 \mathrm{pmol} / \mathrm{l}$ after $120 \mathrm{~min}]$, reaching concentrations equal to the responses seen in healthy subjects. During the hyperglycaemic clamps with concomitant infusion of GIP in Type II diabetic patients, there was a tendency to a small increase in glucagon secretion in the first part of the study followed by a minor decrease in the late response.

The amounts of glucose infused during the first hour of the hyperglycaemic clamps (means \pm SEM) in the Type II diabetic patients were; GLP-1: $25.6 \pm 2.8 \mathrm{~g}$; low GIP: $17.3 \pm 2.0 \mathrm{~g}$; high GIP $14.5 \pm 3.0 \mathrm{~g}$ and no incretin hormone: $19.3 \pm 3.2 \mathrm{~g}$ (Fig. 6). Corresponding results, representing the amount of glucose infused during the second hour of the hyperglycaemic clamps, were $36.9 \pm 5.1 \mathrm{~g}, 15.7 \pm 2.0 \mathrm{~g}, 13.9 \pm 2.5 \mathrm{~g}$ and $15.1 \pm$ $2.9 \mathrm{~g}$ of glucose, respectively. The amount of glucose infused during both the first and second hour of the hyperglycaemic clamp was higher during GLP-1 stimulation compared to GIP stimulation (first hour; $p<0.02$, second hour $p<0.01$ ).

\section{Discussion}

The design of our investigation was inspired by previous studies which indicated that it is possible to use GLP-1 as a tool for evaluating the maximal beta-cell insulin responses and C-peptide responses in Type II diabetic patients [8]. Stimulating the beta cell with $2.5 \mathrm{nmol}$ of GLP-1 combined with increases of plasma glucose concentration to $15 \mathrm{mmol} / \mathrm{l}$ provides a strong insulinotropic stimulus, close to the maximal secretory effect obtained with arginine during a $30 \mathrm{mmol} / \mathrm{l}$ hyperglycaemic clamp [8]. By comparing the insulin and $\mathrm{C}$-peptide responses to GIP with the maximal responses to GLP-1, it should be possible to gauge the beta-cell responsiveness to GIP in diabetic patients independent of their impaired secretory capacity. It is often assumed that GLP-1 is more potent than GIP [19], but by infusing GIP at three times the rate of GLP-1, we sought to compensate for any difference in potency. In spite of this it was impossible to obtain 

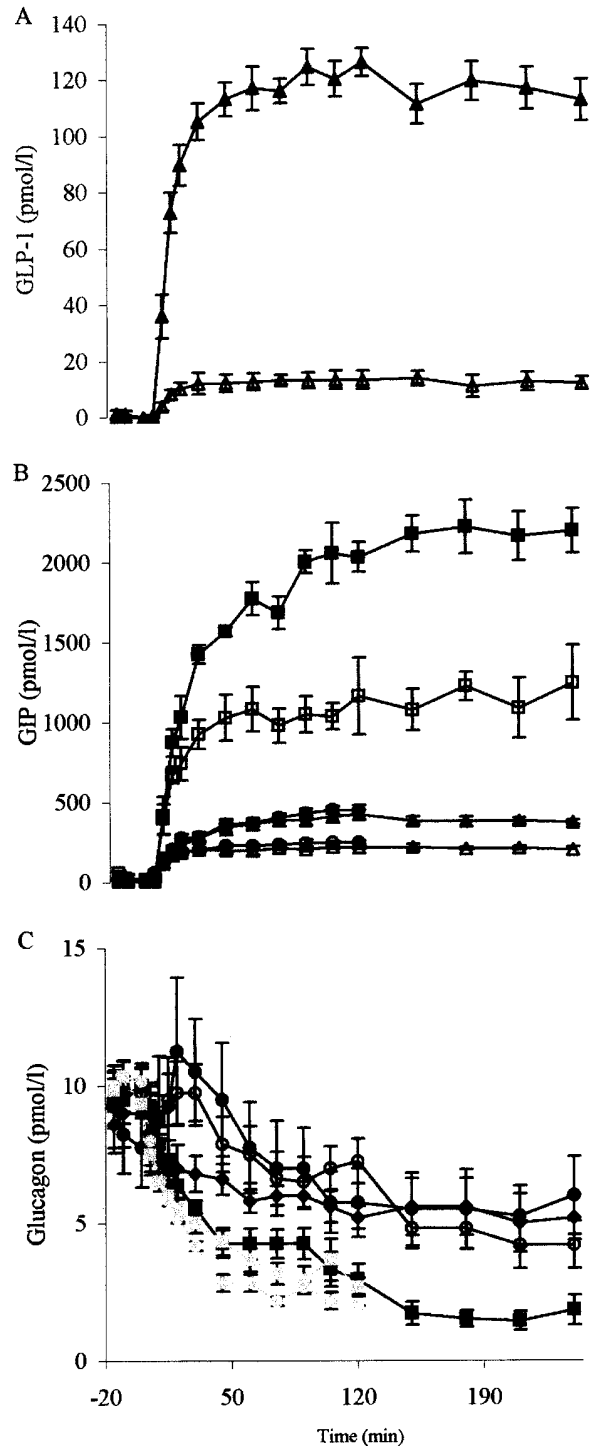

similar responses with the two hormones, either in Type II diabetic patients or in healthy subjects. The peak insulin responses to GIP injection averaged only $62 \%$ of the response to GLP-1 in the healthy subjects versus $59 \%$ in the Type II diabetic patients (NS). Thus, in our study the Type II diabetic patients were characterised by a decreased "early phase" response to both stimuli, but their relative responses to GIP and GLP-1 stimulation were exactly the same as in the healthy subjects.

The hyperglycaemic clamp experiments showed that GIP greatly augmented both "early phase" (0-20 min) and "late phase" (20-120 min) insulin secretion in the healthy subjects. In the Type II diabetic patients, the "early phase" insulin response was grossly reduced and delayed, both in response to glucose alone or to glucose plus incretin hormones but, in agreement with findings in part one, both GIP and GLP-1 augmented the "early phase" response to values similar to those observed in protocol 1 (and also similar to those observed in response to ingestion of a mixed meal [4]). The GLP-1 induced enhancement of insulin secretion persisted

Fig. 5A-C. A Plasma GLP-1 during GLP-1 stimulation in Type II diabetic patients: total GLP-1 (solid triangles) and intact GLP-1 (open triangles). B Plasma GIP in Type II diabetic

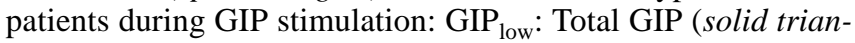

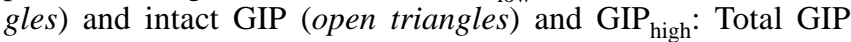
(solid squares) and intact GIP (open squares) and healthy subjects: total GIP (solid circles) and intact GIP (open circles). C Glucagon concentrations during all four different experimental days. Patients: day $1_{\mathrm{GLP}-1}$ (solid squares), day $2_{\text {Low GIP }}$ (open circles), day $3_{\text {High GIP }}$ (solid circles), day $4_{\text {Glucose }}$ (solid diamonds). Healthy subjects: day $2_{\text {Low GIP }}$ (grey circles) and day $4_{\text {Glucose }}$ (grey squares). Data are means \pm SEM

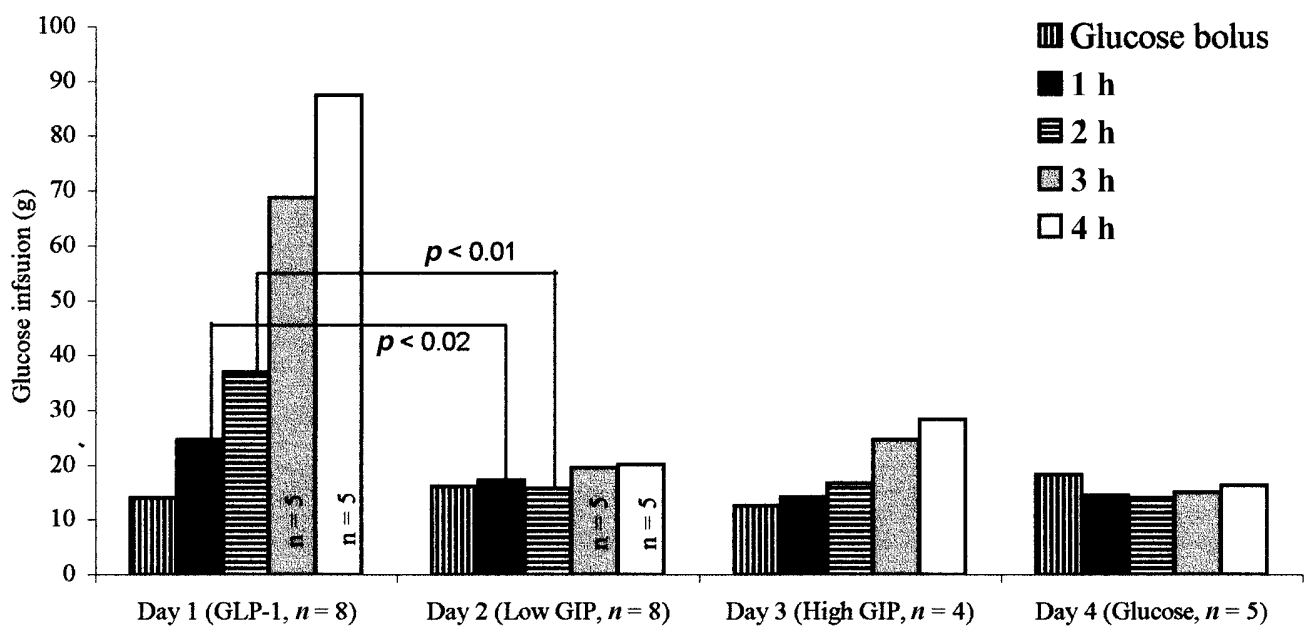

Fig. 6. Glucose infusion during the hyperglycaemic clamp. Total amount of glucose $(\mathrm{g})$ infused for increase of plasma glucose to $15 \mathrm{mmol} / \mathrm{l}$. $p$ values refer to difference between glucose infusion in Type II diabetic patients after GLP-1 and low dose GIP 
throughout the experiment, so that the late response was indistinguishable from the response to glucose alone in the normal subjects. In contrast, there was very little effect of GIP in the "late phase", regardless of the infusion rate. Correspondingly, during the GLP-1 stimulation, greatly increasing amounts of glucose were needed to maintain the clamp, whereas during GIP infusion, there was no difference between the amount of glucose infused during GIP plus glucose compared to glucose alone.

The glucagon responses show that the glucose-mediated inhibition of glucagon secretion was impaired in the patients as expected [20]. In the healthy subjects, addition of GIP did not inhibit glucagon secretion further, and in the patients there was even a tendency towards higher glucagon concentrations with GIP compared to glucose alone. In contrast, with GLP-1, glucagon secretion was strongly inhibited in patients at the end of the clamp. These remarkable results show that GLP-1 is capable of conveying normal responsiveness to glucose to both the $\alpha$-cells and beta cells of the pancreatic islets in patients with Type II diabetes.

The differential responsiveness to GIP and GLP-1 is surprising, because their beta-cell signal transduction mechanisms involve many common steps, except for transmission via closely related, but highly specific receptors for each hormone [21, 22, 23]. Several studies have shown that intracellular actions of the two hormones are similar: they generate identical changes of membrane potential, intracellular calcium responses, membrane currents, and cAMP responses $[24,25,26]$. Furthermore, the insulinotropic effects of both peptides are similarly potentiated by sulfonylurea treatment and similarly augmented in the genetically obese $(f a / f a)$ Zucker rat $[27,28]$. We previously hypothesised, that the lack of a functional receptor was the cause of the impaired response to GIP in Type II diabetic patients [29]. It was, therefore, concluded that the two receptors are likely to activate the same intracellular machinery [30]. Molecular genetic studies have shown sequence variations in the human GIP receptor $[31,32]$, but no clinically significant mutations. Our investigation shows that it is unlikely that the GIP receptors are not expressed on the pancreatic beta cell of the patients, since the early, relative response to GIP compared to GLP-1 was the same as in healthy subjects. What, then is the mechanism of the almost abolished beta cell "late-phase"-responses to GIP in the Type II diabetic patients? To investigate whether a decreased sensitivity of the GIP receptor was part of the explanation, the study included an experimental day where a very high dose of GIP (16 pmol/kg body weight $/ \mathrm{min}$ ) was given. Thus, in spite of pharmacological concentrations of GIP (values were much higher than those observed after meal ingestion), which should compensate not only for the difference in potency of the two hormones but also for a de- creased affinity of GIP for its receptor in Type II diabetes mellitus, it was still impossible to generate a significant "late-phase" response in the Type II diabetic patients. Furthermore, the results obtained during the 4-h clamp were qualitatively similar to those obtained with the 2-h clamp, indicating that a delayed response to GIP in the patients could not explain the difference in the 2-h clamp experiments. In the 2-h clamp experiments, insulin secretion in response to GLP-1 stimulation was still increasing, making it impossible to evaluate the full effect of GLP-1, but in the 4-h clamp experiments, a plateau was eventually reached after $150 \mathrm{~min}$.

Recent studies have shown a reduced insulinotropic effectiveness of GIP in 50\% of glucose tolerant first-degree relatives of Type II diabetic patients in comparison to healthy subjects and it was hypothesised that a new phenotypic abnormality in such subjects could be genetically determined [33]. The most reasonable explanation of the missing "late phase" response to GIP in Type II diabetic patients is, therefore, a GIP postreceptor defect of the intracellular machinery, which could be genetically determined.

In conclusion, we have shown that in Type II diabetic patients, the "early phase" insulin response to glucose is impaired, but enhanced by both GLP-1 and GIP; in contrast, GIP stimulation is unable to improve the "late phase" insulin secretion in Type II diabetic patients whereas GLP-1 could actually normalise this. This defective response to GIP could contribute to the pathogenesis of Type II diabetes mellitus and we hypothesise that it is due to some kind of genetic defect, perhaps in the intracellular actions of GIP.

Acknowledgements. We thank J. Purtoft, L. Bagger and S. Reimer for their technical assistance. The study was supported by the Danish Diabetes Association and the Novo Nordisk Foundation.

\section{References}

1. Creutzfeldt W, Nauck M (1992) Gut hormones and diabetes mellitus. Diabetes Metab Rev 8:149-177

2. Nauck M, Stockmann F, Ebert R, Creutzfeldt W (1986) Reduced incretin effect in Type II (non-insulin-dependent) diabetes. Diabetologia 29:46-52

3. Nauck MA, Homberger E, Siegel EG et al. (1986) Incretin effects of increasing glucose loads in man calculated from venous insulin and C-peptide responses. J Clin Endocrinol Metab 63:492-498

4. Vilsboll T, Krarup T, Deacon CF, Madsbad S, Holst JJ (2001) Reduced postprandial concentrations of intact biologically active glucagon-like peptide 1 in type 2 diabetic patients. Diabetes 50:609-613

5. Elahi D, McAloon-Dyke M, Fukagawa NK et al. (1994) The insulinotropic actions of glucose-dependent insulinotropic polypeptide (GIP) and glucagon-like peptide-1 (7-37) in normal and diabetic subjects. Regul Pept 51:63-74 
6. Nauck MA, Heimesaat MM, Orskov C, Holst JJ, Ebert R, Creutzfeldt W (1993) Preserved incretin activity of glucagon-like peptide 1 [7-36 amide] but not of synthetic human gastric inhibitory polypeptide in patients with type-2 diabetes mellitus. J Clin Invest 91:301-307

7. Meneilly GS, Bryer-Ash M, Elahi D (1993) The effect of glyburide on beta-cell sensitivity to glucose-dependent insulinotropic polypeptide. Diabetes Care 16:110-114

8. Vilsboll T, Toft-Nielsen MB, Krarup T, Madsbad S, Dinesen B, Holst JJ (2000) Evaluation of beta-cell secretory capacity using glucagon-like peptide 1 . Diabetes Care 23:807-812

9. Report of the Expert Committee on the Diagnosis and Classification of Diabetes Mellitus (1997) Diabetes Care 20:1183-1197

10. Alberti KG, Zimmet PZ (1998) Definition, diagnosis and classification of diabetes mellitus and its complications. Part 1: diagnosis and classification of diabetes mellitus provisional report of a WHO consultation. Diabet Med 15:539-553

11. Heding LG (1975) Radioimmunological determination of human C-peptide in serum. Diabetologia 11:541548

12. Faber OK, Binder C, Markussen J et al. (1978) Characterization of seven C-peptide antisera. Diabetes 27 [Suppl 1]: 170-177

13. Krarup T, Madsbad S, Moody AJ et al. (1983) Diminished immunoreactive gastric inhibitory polypeptide response to a meal in newly diagnosed type I (insulin-dependent) diabetics. J Clin Endocrinol Metab 56:1306-1312

14. Krarup T, Holst JJ (1984) The heterogeneity of gastric inhibitory polypeptide in porcine and human gastrointestinal mucosa evaluated with five different antisera. Regul Pept 9:35-46

15. Deacon CF, Nauck MA, Meier J, Hucking K, Holst JJ (2000) Degradation of endogenous and exogenous gastric inhibitory polypeptide in healthy and in type 2 diabetic subjects as revealed using a new assay for the intact peptide. J Clin Endocrinol Metab 85:3575-3581

16. Orskov C, Rabenhoj L, Wettergren A, Kofod H, Holst JJ (1994) Tissue and plasma concentrations of amidated and glycine-extended glucagon-like peptide I in humans. Diabetes 43:535-539

17. Gutniak MK, Larsson H, Heiber SJ, Juneskans OT, Holst JJ, Ahren B (1996) Potential therapeutic levels of glucagon-like peptide I achieved in humans by a buccal tablet. Diabetes Care 19:843-848

18. Orskov C, Jeppesen J, Madsbad S, Holst JJ (1991) Proglucagon products in plasma of noninsulin-dependent diabetics and nondiabetic controls in the fasting state and after oral glucose and intravenous arginine. J Clin Invest $87: 415-423$

19. Kieffer TJ, Habener JF (1999) The glucagon-like peptides. Endocr Rev 20:876-913
20. Le Febvre (1991) Abnormal secretion of glucagon. In: Samuels E (ed) The endocrine pancreas. Raven Press, New York, pp 191-205

21. Gallwitz B, Witt M, Morys-Wortmann C, Folsch UR, Schmidt WE (1996) GLP-1/GIP chimeric peptides define the structural requirements for specific ligand-receptor interaction of GLP-1. Regul Pept 63:17-22

22. Goke R, Trautmann ME, Haus E et al. (1989) Signal transmission after GLP-1(7-36)amide binding in RINm5F cells. Am J Physiol 257:G397-G401

23. Gromada J, Holst JJ, Rorsman P (1998) Cellular regulation of islet hormone secretion by the incretin hormone glucagon-like peptide 1. Pflugers Arch 435:583-594

24. Ding WG, Gromada J (1997) Protein kinase A-dependent stimulation of exocytosis in mouse pancreatic beta-cells by glucose-dependent insulinotropic polypeptide. Diabetes 46:615-621

25. Gromada J, Rorsman P, Dissing S, Wulff BS (1995) Stimulation of cloned human glucagon-like peptide 1 receptor expressed in HEK 293 cells induces cAMP-dependent activation of calcium-induced calcium release FEBS Lett 373:182-186

26. Gromada J, Dissing S, Bokvist K et al. (1995) Glucagonlike peptide I increases cytoplasmic calcium in insulinsecreting beta TC3-cells by enhancement of intracellular calcium mobilization. Diabetes 44:767-774

27. Gutniak MK, Juntti BL, Hellstrom PM, Guenifi A, Holst JJ, Efendic S (1996) Glucagon-like peptide I enhances the insulinotropic effect of glibenclamide in NIDDM patients and in the perfused rat pancreas. Diabetes Care 19:857-863

28. Jia X, Elliott R, Kwok YN, Pederson RA, McIntosh $\mathrm{CH}$ (1995) Altered glucose dependence of glucagon-like peptide I(7-36)-induced insulin secretion from the Zucker (fa/fa) rat pancreas. Diabetes 44:495-500

29. Holst JJ, Gromada J, Nauck MA (1997) The pathogenesis of NIDDM involves a defective expression of the GIP receptor. Diabetologia 40:984-986

30. Gromada J, Holst JJ, Rorsman P (1998) Cellular regulation of islet hormone secretion by the incretin hormone glucagon-like peptide 1. Pflugers Arch 435:583-594

31. Almind K, Ambye L, Urhammer SA et al. (1998) Discovery of amino acid variants in the human glucose-dependent insulinotropic polypeptide (GIP) receptor: the impact on the pancreatic beta cell responses and functional expression studies in Chinese hamster fibroblast cells. Diabetologia 41:1194-1198

32. Kubota A, Yamada Y, Hayami T et al. (1996) Identification of two missense mutations in the GIP receptor gene: a functional study and association analysis with NIDDM: no evidence of association with Japanese NIDDM subjects. Diabetes 45:1701-1705

33. Meier J, Hucking K, Holst J, Deacon CF, Schmiegel W, Nauck M (2001) Reduced insulinotropic effect of gastric inhibitory polypeptide in first-degree relatives of type 2 diabetes. Diabetes 50:2497-2504 